\title{
Effectiveness of the use of electronic educational blogs in teaching computers on the achievement of students
}

\author{
Abdul Munem Hasan Ahmed Ali \\ Department Biology, College of Education, University of Samarra, Iraq
}

\section{Article Info}

Article history:

Received Sep 23, 2018

Revised Apr 17, 2019

Accepted Jun 1, 2019

\section{Keywords:}

Educational Blogging

Effectiveness

Information Retention

Learning Achievement

Teaching

\begin{abstract}
The purpose of this research was to know the effectiveness of using educational blogs in teaching computers on the achievement of students in the second year in the College of Education and retention of information. The researcher used the semi-experimental method. The sample of research consisted of (36) students in the second year in the department of Biology, the College of Education at the University of Samarra has been divided into two groups, one of which consists of (18) students which has been considered as control group and has been studied using the classical method, and the experimental group which consisted of 18 students studied using the educational blog. Both groups (experimental and control) were similar in number and equal in the number of variables that could affect the safety of experimental design of the research. The researcher choose Chapter 4 of (Microsoft PowerPoint 2010) and Chapter 5 (Inserting Objects and Adding Movements in Microsoft PowerPoint 2010) from Computer Basics Part 2, which is taught to students of the second stage at the College of Education / University of Samarra, the researcher used the test of achievement in the computer material, prepared by the researcher consists of (50) paragraphs of the multiple choice, and to test the validity of assumptions used researcher statistical packages program (SPSS): The research has been found the following results: there was significant difference at the level of significance (0.05), between the mean scores of the experimental group studied using the educational blogs and the mean scores of the control group students who studied using the traditional method in the post-test for the experimental group; there are statistically significant differences at the level of significance (0.05) among the mean score of the experimental group students studied using the educational blogs, and the mean score of the control group students studied using the traditional method of post-test to retain information for the benefit of the experimental group. In light of the findings of the current research, the researcher recommended a number of recommendations, of which the need to use electronic educational blogs in teaching computers in the colleges of education, and the need to work on the processing of computer laboratories in colleges, institutes and educational institutions Internet service.
\end{abstract}

Copyright $\odot 2020$ Institute of Advanced Engineering and Science. All rights reserved.

\section{Corresponding Author:}

Abdul Munem Hasan Ahmed Ali,

Department Biology, College of Education,

University of Samarra, Iraq.

Email: abdalmonem424@gmail.com

\section{INTRODUCTION}

Today, our world is witnessing a rapid race towards the use and applying of modern technologies in education, whether in universities, schools or other learning institutions, making modern technology a very difficult process. Modern changes occur at a high speed, increasing the gap between our world Arab and 
developed world, and in our time it became known to all that the owner of science, and modern technologies, it has the right to stay and control, which necessitates the Arab countries to race time, and try to upgrade everything related to the educational process of modern books, and teaching aids to help increase the effectiveness and raise the level of academic achievement of students, as well as the use of digital technology represented by the Internet and other means which are used by the network as a necessity for the success of the modern educational system [1]. E-learning is one of the most important modern technologies that can be used in the field of education. E-learning helps students and learners to learn through interactive multimedia content including sound, image, movement and text. E-learning is an important educational pattern, which is the basis of the modern scientific and technological revolution that swept the world. Through the comprehensive development, which is open to the Internet and providing them to users at high speeds, The concept of e-learning has changed and its presentation and methods of interaction with it included more interactive aspects, which led to the occurrence of the so-called second generation of e-learning, which is interested in the employment of programs that are important from the social point of view such as blogs Which include Blogs and Wikis. In [2], points out that learning weblogs are among the most prominent applications of web2.0, which is a revolution among users of the web because of its many characteristics including interactive, privacy, mutual participation and ease of use. The educational blogs are one of the most important and outstanding applications of the second generation of e-learning, which the teachers began to implement in order to serve the courses and the continuity of communication with their students. The blogs have a set of characteristics and specifications that distinguish them from the first generation techniques of elearning. On the other hand blogs Can be considered as one of the types of content management systems where teaching can be used to publish courses and to discuss with students, on the other hand, blogs are easy to use and construction so that any user Blood to create a blog of his own without having prior knowledge of design and programming websites [3]. A large number of different studies and researches have confirmed the effectiveness of educational blogs in the teaching of various courses and at all levels of study. The study of Teknarslan [4]: which proved that the blogs have a positive effect on the increase in student achievement in the computer curriculum, $[3,5,6]$ : which referred to the effectiveness of electronic educational blogs in the development of educational achievement and learning languages and thinking skills and survival of the impact of learning. According to [7]: The University of Dickinson in the United States has created a special system to host blogs and wikis so that they can request them to publish their research and meals electronically instead of using the usual method. Therefore, the researcher believes that through the use of new techniques such as educational blogs in teaching computers for students in the second year of the College of Education Samarra, it will help to create an attractive learning environment that enables students to learn according to their potential and ability and thus will work to increase the academic achievement of students, many of studies have confirmed the efficiency and importance of the use of electronic blogs in increasing students' academic achievement such as the study of [8,9].

\section{THE FIRST TOPIC: DEFINITION OF RESEARCH}

\subsection{First: - Research's Problem:}

The researcher noticed through his work as a lecturer at the University of Samarra/College of Education / Biology Department, the low level of students in the second year in the Department of Biology in computer science lesson. The students' grades were below the required level in the first semester exams, as well as the poor level of cooperation and participation among students during the lecture. Low level of motivation for students towards learning, as well as the tight time of the quota and the large numbers of students, which does not allow students to participate and react with each other adequately, all these things prompted the researcher to search for new ways and methods of teaching are appropriate and attractive to suit students and attract them to the subject matter, In the teaching of computers for students in the second stage in the Department of Biology at the College of Education.

\subsection{Second: - The Importance of Research:}

a) This research presents a new model in modern teaching methods, as it uses a contemporary method in the process of education through the use of electronic educational blogs in the teaching of computers.

b) Assisting teachers in order to take advantage of modern techniques based on the web and work to be employed in teaching courses.

c) This research provides a blog electronic educational rich lessons and PowerPoint presentations and educational videos that help rise the achievement of students in the second stage in the computer

d) Proposing a set of recommendations that can contribute to the activation of the use of educational blogs in teaching courses. 


\subsection{Third: - Research Objectives}

a) Design of electronic blogs teaching for computers lesson for students in the second year in the Department of Biology according to the standards of design blogs of education.

b) To recognize the effectiveness of the use of educational blogs in teaching computers on the achievement of students in the second stage in the College of Education and retention of information.

\subsection{Fourth: - Research Limits}

a) The objective limits: The research will be limited to the fourth chapter and the fifth chapter of the book the basics of computer Part II, which is study to students of the second stage in the colleges of education in Iraq, where the fourth chapter (Introduction to Microsoft PowerPoint 2010) and includes Chapter V (inclusion of objects and the addition of movements in Microsoft PowerPoint 2010).

b) Locative boundaries: University of Samarra / College of Education.

c) Time Limits: The second semester of the academic year (2017-2018).

\subsection{Fifth:- Method of Research}

The researcher used a semi-experimental approach to its relevance to the research objectives.

\subsection{Sixth: Research Hypotheses}

a) There were no significant differences at the level of significance (0.05) between the mean scores of the main experimental group and, the mean score of the control group in the final achievement test for the computer.

b) There were no statistically significant differences at the level of significance $(0.05)$ between the mean scores of the experimental group and, the mean score of the students in the control group in the retention test for the computer material.

\subsection{Seventh: - Search Terms}

The activity:

a) In [10] Defines effectiveness as "the ability to influence and achieve goals or inputs in order to achieve the desired results and reach them to the maximum extent possible."

b) The researcher defines procedural efficiency as: The ability of the electronic educational blogs to effect the achievement of students in the second stage in the computer in the current research.

\section{BLOGS}

a) Known by [11] as: It is a website on the Internet enables users and learners to carry out the dissemination and coordination of information and data, whether (text, audio or video or video clips or blogs links) and are suspended so that Dated in chronological order from the most recent to the oldest published, and various search engines on the Internet can easily access them.

b) The procedural definition of the electronic blogs: It is an educational page designed by the researcher on the Internet contains information and data on Chapter IV (Introduction to Microsoft PowerPoint 2010) and Chapter V (Drawers objects and the addition of movements in Microsoft PowerPoint 2010) This course includes information and data (lectures and educational videos) that allow students to interact with their components through writing, discussion and participation.

\section{TEACHING}

a) Defines teaching as: all the possibilities and conditions provided by the teacher in a given teaching position, as well as all the actions taken by the teacher, in order to help the students achieve the goals set for that position.

b) The procedural definition of teaching: It is a continuous activity has been planned, and this activity aims to teach computers for students in the second phase of the College of Education University of Samarra using the electronic blog of education in order to increase the academic achievement of students.

\section{ACADEMIC ACHIEVEMENT}

a) Defines it: is the quantity of information and skills that students receive, expressed in degrees in the tests prepared for this purpose, as a result of their study of a specific object, program or specific learning unit. 
b) The researcher defines practically as: the quantity of information and acquired by students of the second stage in the College of Education / University of Samarra after the study of Chapter IV (Introduction to Microsoft PowerPoint 2010) and Chapter V (inclusion of objects and the addition of movements in Microsoft PowerPoint 2010). Determined by the grades got by the students in the final achievement test prepared by the author.

\section{INFORMATION RETENTION}

a) In [12] Defined it as: It is the capacity of students to remember datum, information and details and their capacity to keep them.

b) The researcher defines the procedure: It is the quantity of information that students can keep them from the object of computer material, which were measured through the degrees obtained in the retention information test, which was conducted for students sample of the study after (three weeks) to apply the final exam Without equipping them with any other information pertaining to the topics studied in the period between the two tests.

\subsection{The Second Topic: The Theoretical Framework and the Previous Studies}

The theoretical framework of educational blogs. Educational blogs are a unique new method that can be used to integrate modern technology into the classroom. This is an easy and understandable way for students to deal with it simply and easily. There are a large number of sites that allow students or learners to create a blog. So that he can continue the process of teaching outside the walls of classrooms at any time, helping students improve the outcomes of their education. In 2004, the term "web2.0" was introduced by Tim Oreille and Dale Dougherty. This term was used to describe modern technical trends, and it has developed a set of characteristics of efficiency, collaboration, and user participation [13]. In [14] defines (web2.0) technology as a new philosophy or method used to provide second-generation Internet services. It relies on the support of connection between Internet users to build electronic-communities. This philosophy is reflected in many of applications which features characteristics and features of web2.0 technology). The most prominent applications are: Blogs, Free Wiki, RSS, and Online Social Networking.

\subsection{The Concept of Blogging}

The blog is called "web log", meaning the web log. The person who publishes and writes is called the blogger. It is called blogging.

In [15] is defined as a web page that is easy to create. It can be edited by one or more bloggers. The blog has a specific topic. The blog posts are arranged in reverse order. The blog allows interaction between its readers And its editors, so that any web browser can comment on the Internet in easy and simple ways.

\subsection{Blog Components}

In $[16,17,3]$ point out that the components of blogs differ from each other according to their different objectives, but share a number of components with each other as follows:

a) The title of the blog (Blog Title): The first thing that a visitor sees to the blog and is considered the most important element of the blog.

b) Titles or posts: means the entries that the blogger inserts into his blog, and may be text input, video clips, images or any other form of data or information, these entries will be dated and showing the date of publication of the subject.

c) Comments: This allows Blog visitors to reply to posts on blog pages.

d) Permalink: for use in other sites or blogs.

e) Track back: In order to track who wrote about a subject published in the blog.

f) The archive of topics: through which the old topics are collected and then arranged in descending order by the date of writing and presented to visitors for ease of reference.

g) RSS feeds: a service added to the blog, where the blogger puts links to his favorite sites, in order to track the new ones, as once you add any new topic to those sites, a summary is sent, so the person who is blogged To constantly contact his favorite sites, all of which saves him time and effort in the search for news and topics in those sites.

h) Blog Rolls: Friendly blogs are a list of blogs that correspond to the goals and topics of the blog and are placed in the blog in order to benefit from them.

i) Pages: They are static, and have a chronological order in the site archiving process, such as the blog's profile page or the blogger's contact page.

j) Categories: These are sections determined by the blogger to put his own blogging according to the appropriate classification such as "diary", technology, and others. 
k) Search Engine Blog:

1) Links: These links are tracked by the blogger and want to be shared by visitors to his blog. These links may be textual, image links, or links to videos.

\subsection{Types of Electronic Blogs}

In [3] points out that blogs can be categorized into several types according to several axes and Figure 1 shows the types of blogs.

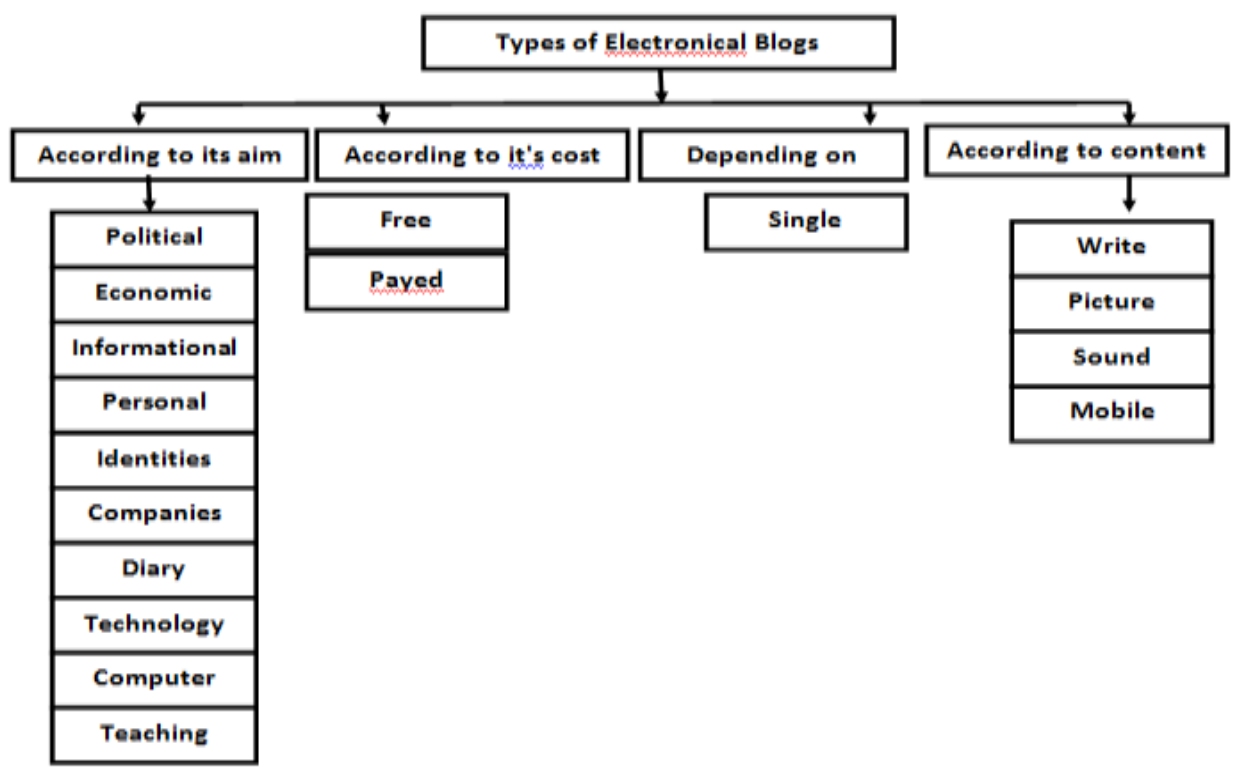

Figure 1. Shows the types of blogs

\subsection{In [18] points to three types of blogs that are frequently used in classrooms:}

a) Teacher's Blogs: This is what the teacher determines and works on, such as exploring sites and exchanging views via the Internet through the use of buttons to suspend access to information about the curriculum.

b) Learner's Blogs: This allows the student to work and participate, where he can add his ideas, and thus encourages students to express themselves.

c) Teacher's Code and students: Here is a process of sharing the code by the teacher and students, and this blog encourages students to carry out the dissemination of images and messages, and this type of codes can facilitate the education based on projects.

\section{ADVANTAGES OF ELECTRONIC BLOGS}

a) Easy in terms of the process of construction as it does not need experience or knowledge of the programming language where there are a lot of mold ready to help in the process of creation.

b) Help break the time and space barrier, where the blogger can perform the codification process at any time he chooses, whether at night or day.

c) Availability of the interaction with the public, which is called feedback, where the public can comment on the issue published.

d) Contribute to save time and effort in the process of codification and printing, and help to preserve the environment by reducing the waste paper for printing.

e) Provides the advantage of automatic extension of the writings and publications, which helps the writer or continental reference to the subject he wants at any time of his choice.

f) The advantage of using multimedia (text, images, audio, video) is available in the blogging process.

g) Contribute to the process of preserving the copyright and printing of writings and publications.

h) Blogs help to promote students' self-motivation by creating a spirit of challenge for students.

i) Blogging is a continuous assessment tool for student learning. Through blogging, the teacher can evaluate all that the student has added to the code since the beginning of the course. 


\section{THE USE OF ELECTRONIC BLOGS IN THE EDUCATIONAL PROCESS}

In [19] refer to a number of educational areas in which blogs can be used:

a) Explanation of courses: where the teacher can put the content of the course that is taught within the code of his own, and direct students to access his blog in order to benefit from the content of the course and the dissolution of duties, and students can write their comments, and the teacher can benefit from the support of the code for multimedia use that Including text, images, audio and video, and can provide student feedback.

b) In classroom management: It is possible to use blogs as an electronic portal contributes to the formation of an educational community, which can be used to deliver courses and instructions to students, or to inform students of important observations.

c) Research in colleges and universities: The blog occupies an important role in providing students with the knowledge and information they need to accomplish their research through the use of the Internet, so the blogs became important tools for researchers to complete their research.

d) In training students and teachers in humiliating skills: It is possible to use blogs to train teachers and students on some technical skills such as the skills of using some modern electronic devices.

e) Communicating with students and assigning them the required duties: It is possible to use electronic blogs to inform students of their meals, even in the absence of students for permanent reasons to break the excuses for students, as well as the use of the code to display ads for each teaching alone, Parents of students, and respond to their inquiries.

f) Student achievement files (electronic bags): It is possible to use blogs to show the achievements of students, and to evaluate and develop their skills; in addition to that students will be more interested in their results because they know it will be published on the Internet by their names.

g) In public libraries and university libraries: Blogs can be used to disseminate information about books in libraries and what services they provide.

h) Means of communication: Blogs are an important and effective means of disseminating information better than paper copies (textbooks).

i) a means of assistance for discussion and dialogue: It is possible to use blogs as a means of assistance for dialogue when a curriculum or subject needs a lot of time to discuss the interlocutor, so putting this subject in the blog and open the discussion to students will help save time for the lecture and will help discuss the subject In all its aspects.

j) Blogs can be used to create an atmosphere of mutual cooperation between students based on mutual respect by following up students with their colleagues' blogs and commenting on them.

\section{EDUCATIONAL OBJECTIVES OF BLOGS}

In $[14,11]$ see that e-blogging aims to achieve a number of goals that concern the teacher and student and the content of the curriculum and the following:

a) Communicate the instructions and requirements of the students' academic courses and help the students communicate with the teachers outside the classroom walls.

b) Provide teachers with the opportunity to browse student blogs and provide encouraging and stimulating feedback.

c) Helps blogging to provide more creativity in the curriculum than those based on the old traditional systems.

d) Blogs help in the exchange of information such as: the dissemination of links to sites useful to students, and encourage interaction between students and their teachers and students with each other.

\subsection{Second: Previous Studies}

9.1.1 In [20] Study:

This study aimed to know the effect of the use of blogs in university education, and what can be added to the educational environment within the classroom. The study sample included (24) graduate students at the College of Education at Hong Kong University, the study used the code to discuss topics related to the decision to use information technology in education. The study showed that the use of the code helped to increase students' academic achievement. The study participants also stressed the importance of the code and helped them facilitate their work. Most students expressed their desire to work. Blogs of their own in the future.

\subsubsection{Fawzia Al-Madhouni's study [3]:}

This study aimed to identify the effectiveness of the use of educational codes in the development of academic achievement and towards it among the students of Qassim University. The researcher used the 
descriptive method based on content analysis, and the semi-experimental method based on the design of the two groups (experimental and control). The study group included (72) female students of the Department of English Language at the College of Science and Arts in Buraidah region. The results of the research were the following:

There are statistically significant differences between the mean score of students of the experimental group (who study using the educational code) and the students of the control group (who study in the usual way) in the achievement test to separate the innovations of learning techniques in favor of the experimental group.

\subsubsection{Salwa Al Masri's Study (2011):}

The study was designed to identify the effectiveness of the use of an educational code in rise the achievement of students in the preparatory stage of abstract concepts in computer material and towards the material. The research sample consisted of 35 students. The data of reserch was divided into two groups (experimental and control) (Arabic Section) in Giza Governorate / Dokki Educational Department. The researcher used the experimental method to apply the research experience. The results of the study showed:

a. There were statistically significant differences at the level of (0.05) between the mean of the experimental group and the control group in the post-achievement test in the first group (expermintal).

b. There are significance differences at the level (0.05) between the mean score of the trend scale of the experimental group and the control group in the application of the dimension of the scale for the benefit of the experimental group.

\subsubsection{Ketchikarno [18]:}

The perpose of study was identify the impact of the use of electronic blogs in the development of writing skills in English. The study sample consisted of (33) students of the first stage who study English language course at Bangkok University. The study sample was divided into (6) A group of (5-6) students, and asked each group to design a blog special on the site (Blogger), the results of the study showed that after the students worked with each other using blogs, it was found that the mean grade of students in writing skills in English in the post-test was higher Of their mean scores in the tribal achievement test, and showed that students have positive attitudes towards the use of blogs in education.

\subsection{Third topic: procedures of the Research: \\ 9.2.1 Experimental Design for Research:}

The design of the two groups (experimental and control) with the post-achievement test was chosen as an experimental form, shown in Table 1, that the researcher sees fit to achieve the goal of this research.

Table 1. Semi-experimental design of the research

\begin{tabular}{ccc}
\hline Group & Experimental treatment & Aimed application \\
\hline Experimental & $\begin{array}{c}\text { Teach by using educational electronic blogs } \\
\text { Control }\end{array}$ & Achievement test \\
\hline
\end{tabular}

\subsubsection{Research Community}

All the students of the second stage in the Department of Biology at the College of Education at the University of Samarra for the academic year (2017-2018) were (177) to be community the research.

\subsubsection{Research Sample}

The researcher selected the research data randomly from the research community. The specimen of the research was 36 students, representing about $20 \%$ of the research community. They were divided into two equal groups and the number of variables affecting the validity of experimental design of the two groups and control

\subsubsection{Research Methodology}

The researcher used the method as a pilot to suit his research objectives.

\subsubsection{Search Variables}

a. Independent variable: educational blogs

b. Dependent variable: academic achievement, retention of information. 


\subsubsection{Search Materials}

a) Determination of scientific material: Identify the researcher in Chapter 4 and Chapter 5 of the second part of Basics of Computer book which is teaches for the students of second year of the college of Education, which chapter 4 consist of (Introduction of Objects and Addition of Movements in Microsoft PowerPoint 2010). Chapter Four (Introduction to Microsoft PowerPoint 2010) includes Chapter 4 and Chapter 5 of the Computer Basics book. (Chapter IV and chapter V) are the scientific material of this research.

b) limitation of learning objectives: The researcher formulated the objectives related to teaching in the light of the general objectives of teaching computers by the teaching staff assigned to teach computers in the College of Education has been formulated in terms of specific teaching objectives, be measurable and the researcher presented to a group of experts and specialists for the statement Its validity, and finally have been definitively determined to be the objectives of the teaching of computers.

\subsubsection{Search tools:}

a) Achievement Test: the researcher prepared a final test that consists of multiple choice questions for the purpose of evaluating the information acquired by the students. The test was presented in its preliminary form to a group of experts and arbitrators. In order to conduct the statistical analysis of this test, 18) students were selected without the research data. The researcher extracted the discrimination coefficient and the difficulty coefficient and the effectiveness of the wrong alternatives for the test paragraphs through the use of the appropriate statistical means, which showed that the test paragraphs are diacritical and their difficulty coefficient of is appropriate. Adequate alternatives were found to be good. Based on this, the test was considered to be honest in order to be applied to the selected research sample. The test instructions were set out as well as the correct method of correcting the test by setting one score for each correct answer.

b) Preparation of the Code for electronic learning: The goal of the establishment of the code was determined, which aimed to provide the educational material for Chapter IV (Introduction to Microsoft PowerPoint 2010) and Chapter V (inclusion of objects and the addition of movements in Microsoft PowerPoint 2010) of computers for students in the second phase in college The University of Samarra, in an electronic format, so that students can refer to it from anywhere and at any time. The code aims at increasing the students' academic achievement in computers.

The search application went through the following steps:

1. The research sample was selected from the second stage students in the Department of Biology College of Education, Samarra University. The research sample consisted of (36) students divided into two groups:

2. The experimental group: The number of (18) students studying using the electronic educational code.

3. Control group: rejected by (18) students studying using the traditional (traditional).

4. The computer lab has been set up. There are (20) computers connected to the internet where the experimental group is taught in the computer lab. The control group will remain in the classroom and be taught in the traditional way.

5. The researcher held a meeting with the students of the experimental group in the computer lab in order to explain and clarify some points:

a. Define the students of the experimental group in the electronic code and its purpose.

b. Adding the students of the experimental group to the blog so that they can participate in it.

c. Define the students of the experimental group how to enter the blog, how to write comments, and how to send

d. Distribute a card to the students of the experimental group, including the e-mail (Google) and password for each student, and the title of the educational code for the computer. (http://www.abdalmonem2018.blogspot.com).

6. The researcher taught the students of the experimental group using the educational blog by two hours each week.

7. The researcher taught the students of the control group traditional teaching method of two hours each week.

8. The teaching process of the experimental group started on the same day that the teaching process of the control group was started. The teaching of the two groups was completed at the same time. Table 2 shows the dates of teaching the two groups: 
Table 2. Shows the dates of teaching the experimental and control groups

\begin{tabular}{ccc}
\hline Day & group & Lesson time \\
\hline Monday & Control & 8-10 A.M \\
& Experimental & $11-1$ P.M \\
\hline
\end{tabular}

9. After the end of the teaching process, which lasted five weeks, the final test was applied to the students of the research groups (experimental and control)..

10. The researcher re-applied the final test to the students of the experimental group and the control group after (three weeks) the application of the first Test, so as to be tested to measure retention of information in students without giving any information to students about the date of the test and without providing them with any Information on the study material during the period between the two Tests.

11. Statistical Methods: In order to get the objectives of research and analysis of evidence used the researcher a number of statistical methods appropriate using the statistical packages program (SPSS).

12. Presentation and discussion of the results:

The first hypothesis: There were statistically significant differences at the level (0.05) between the mean scores of the experimental group and the control group students in the final achievement test of the computer.

To test the validity of this hypothesis, the T-Test was used to denote the differences between the independent and heterogeneous samples in Table 3. Table 3 shows that there are significant differences at the level of (0.05) between the mean scores of the experimental group studied using the educational blogs and the mean scores of the control group students who studied using the traditional method of the postachievement test in favor of the experimental group.

1. This can be attributed to the educational code of the presentation of attractive and interesting content computer material to ensure the use of lectures, photos, multimedia and video clips, in addition to easy access to the blog, all of this contributed to the increase in the educational achievement of students experimental group.

2. This finding is in line with the [20, 3, 21-23].

a. The second hypothesis: There are no significant differences at the level of significance $(0.05)$ between the mean scores of the experimental group and the control group students in the retention test of the information of the computer.

Table 4 shows that there are significant differences at the level of significance $(0.05)$ between the mean scores of the experimental group studied using the educational blogs and the mean scores of the control group students who studied using the classic method of retaining the information for the experimental group $[24,25]$.

Table 3. Comparison of the mean scores of the experimental group and the control group in the post-test of scholastic achievement

\begin{tabular}{|c|c|c|c|c|c|c|c|c|}
\hline $\begin{array}{l}\text { Dependent } \\
\text { variable }\end{array}$ & Group & $\begin{array}{l}\text { Sample } \\
\text { size }\end{array}$ & $\begin{array}{l}\text { Mean } \\
\text { score }\end{array}$ & $\begin{array}{l}\text { standard } \\
\text { deviation }\end{array}$ & $\begin{array}{c}\text { Free } \\
\text { degree }\end{array}$ & $\begin{array}{l}\text { Calculated }(\mathrm{T}) \\
\text { value }\end{array}$ & $\begin{array}{l}\text { Probability } \\
\text { Value (Sig) }\end{array}$ & Statistical function \\
\hline
\end{tabular}

Table 4. Comparison of the mean scores of the experimental and control students in the post-test of retention of information for the computer material

\begin{tabular}{ccccccccc}
\hline $\begin{array}{c}\text { Dependent } \\
\text { variable }\end{array}$ & Group & $\begin{array}{c}\text { Sample } \\
\text { size }\end{array}$ & $\begin{array}{c}\text { Mean } \\
\text { score }\end{array}$ & $\begin{array}{c}\text { standard } \\
\text { deviation }\end{array}$ & $\begin{array}{c}\text { Free } \\
\text { degree }\end{array}$ & $\begin{array}{c}\text { Calculated } \\
(\mathrm{T}) \text { value }\end{array}$ & $\begin{array}{c}\text { Probability } \\
\text { Value (Sig) }\end{array}$ & $\begin{array}{c}\text { Statistical function } \\
\text { (Sigaterence is }\end{array}$ \\
\hline $\begin{array}{c}\text { Retention Of } \\
\text { Information }\end{array}$ & $\begin{array}{c}\text { Control } \\
\text { experimental }\end{array}$ & 18 & 29.11 & 4.93 & 34 & -7.436 & 0.000 & Differen \\
\hline
\end{tabular}

This is due to the fact that the students of the experimental group achieved better results than the students in the control group in the test of retention of information to the use of educational blogs, which provide new and exciting ways to teach computers through the use of videos and PowerPoint presentations, and provide links related to the computer, Is great in attracting students' attention and increasing their attention towards learning and helping them keep information longer [26]. 


\section{CONCLUSIONS}

First, The use of educational blogs in teaching computers' lesson had a significant positive effect in increasing the achievement of students in the second year in computer's lesson. Second, the use of educational blogs in teaching computers' lesson had a significant positive effect on the retention of information among students in the second year for a longer period. Last, the use of educational blogs in teaching computer's lesson, an important and useful in the educational process, because it ensures that the student access to additional information and enhance the explanatory material taught in the traditional lecture.

\section{RECOMMENDATIONS}

1. Work on holding training courses in order to raise awareness and encourage teaching staff in universities to use electronic educational blogs in the process of teaching in order to facilitate and improve the educational process.

2. The need to train students in universities on the use of blogs in order to benefit from them in the educational process.

3. Support the new trend for the integration of information technology and modern technological innovations within the educational environment and promote positive trends towards use in the teaching process.

4. It is necessary to have each teaching electronic code of its own, which includes the content of the study of the course material that is taught in addition to lectures and references for the benefit of students.

5. Needing to provide integrated computer laboratories in universities with the provision of Internet service in those laboratories.

It is necessary for society to understand that modern technological innovations have become a reality that must be dealt with. It is no longer an option. The society must try to change the old view of the traditional educational process into a new and open thinking that contributes to building a modern technological generation with distinct technical skills.

\section{REFERENCES}

[1] Abdel Basset, Hussein Mohamed Ahmed.Is the educational code educational value. Available on the site on , 2011, 16/12/2017: http://hussainbaset.blogspot.com

[2] Faraj, Abdul Rahman. Blogging with special reference to the codes of libraries and libraries, informatics, 2006, No. 14 available on http://www.informatics.gov.sa/details.php?id=141

[3] Madhouni, Fawzia. Effectiveness of the use of educational codes in the development of achievement and direction towards the students of the University of Qassim, unpublished $\mathrm{PhD}$ thesis, Department of Curriculum and Instruction, College of Education, Qassim University, Qassim, Saudi Arabia, 2010.

[4] Tekinarslan, e."Reflection on effects of blogging on students achievement and knowledge acquisition in issues of instructional technology", 2010, vol.7.no (11), pp.33-45.

[5] Al-Ghamdi, Farid and Salem, Mohammed . "A strategic impact of using educational codes in developing critical thinking skills and maintaining the impact of learning among the students of Islamic disciplines at the College of Education, Umm Al-Qura University, Al Riyadh, Saudi Arabia”, 2010.

[6] Li, et al. "Blogging For Teaching And Learning :An Examination Of Experience Attitudes And Levels Of Thinking ,Contemporary Educational Technology", 2013, 4(3),172-186

[7] Bryant, Todd. Social software in academia. educause review, 2006, 29(2),61-64 http://net.educause.edu/ir/library/pdf/eqm0627.pdf

[8] Omran, Khalid Abdul Latif Mohammed. "Effectiveness of the use of educational codes in the teaching of geography on cognitive achievement and the development of geographical and motivational research skills of students in the first grade secondary, the educational magazine, 2012, No. 31, ArabiA

[9] Saidi, Omar bin Salem. Effectiveness of the use of educational codes in the development of cognitive achievement of the skills of classroom management, unpublished master thesis, Department of Curriculum and Teaching Methods, College of Education, Al-Azhar University, Cairo, Egypt, 2013.

[10] Zeitoun, Kamal Abdel-Hamid. Teaching his skills, Cairo, the world of books, 2002.

[11] Abdul Basset, Hussain Muhammad. "Reality and Presentations for the Use of Blogging in Teaching by Teachers and Teachers of Social Sciences in Saudi Arabia". Educational and Psychological Sciences, 2013, Vol. (14), No. 2, Cairo, Egypt.

[12] Oxford, Advanced Learners Dictionary Of Current English, Fifth Edition By Jana Than Crothers Oxford, University Press, 1998.

[13] Halasah, Muhammad. The Use of NGOs in the Gaza Strip for Social Networking in Enhancing their Relationship with the Public, Master Thesis, College of Commerce, Islamic University, Gaza, Palestine, 2013. 
[14] Amir-Mohammad Golmohammadi, Reza Tavakkoli-Moghaddam ， Fariborz Jolai \& Amir-Hossein Golmohammadi.(2014). "Concurrent cell formation and layout design using a genetic algorithm under dynamic conditions," UCT Journal of Research in Science, Engineering and Technology, 2, Issue 1,pp.08-15.

[15] Al-Mehdhar, Abeer. "Impact of proposed electronic code on the development of creative writing skills among high school students", 3rd International Conference on e-learning and distance education, Riyadh, Saudi Arabia, 2013.

[16] Fitzgibbon k. teaching with wikis blogs podcasts \& more. Scholastic Inc, New York ,USA, 2010.

[17] Thompson Mark.(S Design Elements Your Blog ,Should Have)Available At: 2010, (Retrieved On 22/6/2016):http://Smashingshare.com//Design-Elements-Blog

[18] Ketchikarno. "Using Blogo to Improve Students Summary Writing Abilities”, Turkish on Line Journal Of Distance Education, 2012, 13(4), 209-219.

[19] Niranjan, D. S. (2016). "W.T.O. AND SUGAR TRADE OF INDIA”. Humanities \& Social Sciences Reviews, 4(1), 41-48. https://doi.org/10.18510/hssr.2016.415

[20] Churchill, D. "Educational Application Of Web2.0:Using Blogs To Support Teaching And Learning", British Journal of Education Technology , 2009, 40 (1), 179-183., Retrieved May 5.2013, From: www.uo59314.blogspot.com/2009/educational-applications-of-20.html

[21] Egyptian, Salwa Fathy. Effectiveness of the use of an educational code in increasing the achievement of students in the preparatory stage of computer abstract concepts and towards the subject. Unpublished Master Thesis, Department of Curriculum and Teaching Methods, College of Education, Cairo, Egypt, 2011.

[22] Elandaloussi Zineb, Benbba Brahim, Ameziane Houdaifa, "The Impact of SCRM strategies on supply chain resilience: A quantitative study in the Moroccan manufacturing industry", International Journal of Supply Chain management, Vol. 6, No. 4, Dec 2017, 70-76.

[23] The Caliph, Hind Sulaiman. "Comparison between the codes and the system of bridges to manage e-learning", the first international conference for e-learning and distance education, Riyadh, Saudi Arabia Available on the website: 2009, 8/5/2017:http://www.elearning -arab-academy.com/elearning-principles/474-2012-04-10-19-39-20.html

[24] Saadi, Sultan Mesfer Mubarak. social networks risk or opportunity? Search submitted to the network Alouka, Medina, Saudi Arabia, available on 2/7/2013:www.saaid.net/book/18/9524..pdf, 2012.

[25] Reason, Ibrahim. "Al-Shamal in Teacher Training Thinking and Creativity", i (1), Riyadh Najd Foundation for Education, Dar Al-Warraq for Printing, Publishing and Distribution, 2004.

[26] Chandar, Vinesh And Chalmers, Christina. Blogs, Wikis And Podcasts: "Collaborative Knowledge Building Tools In Adesign And Technology Course.Journal Of Learning Design”, 2010, 3(2).Pp.35-49. 